
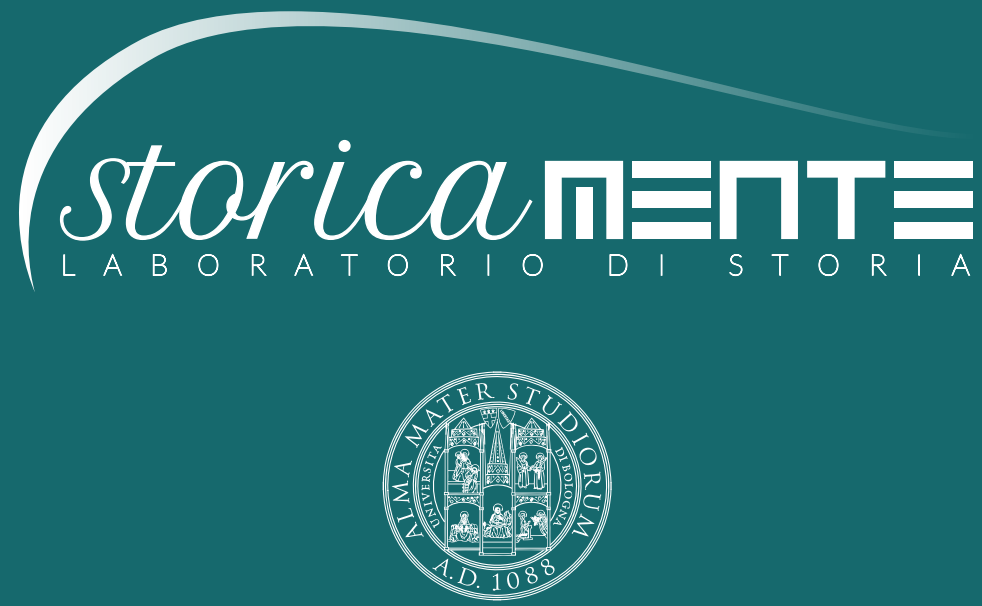

ALMA MATER STUDIORUM

Università di Bologna

Dipartimento di Storia Culture Civiltà

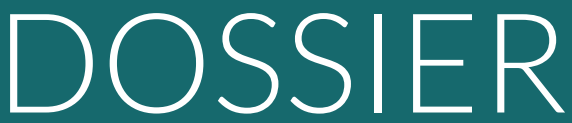

Representations of Fear in History

Empirical / Practical evidence and Methodological Issues 


\section{STORICAMENTE.ORG}

\section{Laboratorio di Storia}

Jan Höltje

Emotional Aspects of Road Safety Issues in Bielefeld, 19791995

Numero $11-2015$

ISSN: $1825-411 \mathrm{X}$

Art. 23

pp. $1-25$

DOI: $10.12977 /$ stor609

Editore: BraDypUS

Data di pubblicazione: $31 / 12 / 2015$

Licenza: CC BY-NC-ND 4.0 International

Articolo sottoposto a revisione paritaria a doppio cieco

Dossier: Representations of Fear in History: Empirical / Practical evidence and Methodological Issues edited by Vito Gironda, Marica Tolomelli 


\title{
Emotional Aspects of Road Safety Issues in Bielefeld, 1979-1995
}

\author{
JAN HÖLTJE \\ Univ. Bielefeld, \\ Fakultät für Geschichtswissenschaft, Philosophie und \\ Theologie
}

This article offers a cultural approach with semantic methods and constructivist premises on the history of mobility. It gives an overview of events taking place in Bielefeld 1979-1995 and analyses the medial and political resonance of traffic issues. The focus is on the perception and communication of insecurities by individual actors, institutions and local media. The proposition is that emotions are structuring the behavior of citizens participating in traffic as well as their social roles when protesting against perceived insecurities.

\section{Introduction}

Traffic security has rarely been treated by the conventional German history of mobility, which is traditionally being situated close to economic history'. Social-psychology and traffic sciences have treated road safety and general security in public spaces to a greater amount. The impact of emotions on traffic and the relevance of security and insecu-

1 For accounts on the history of mobility in Germany after 1945 see: Roth 2009, 4764; Roth 2009, 11-28; Schiedt 2010; Dienel 2007; Dienel 2010, 12; Bergmann 2009, 105-130; Niemann 1999, 12; Fraunholz 2002, 7ff; Böhm 2006, 12; Briggs 1977, 12. 
rity for the political communication were researched only seldom and barely exhaustive. The historiographical diagnosis stands in contrast to the sources in local contexts which enable different perspectives. From the late 1970s to early 1990s road safety issues were a part of daily life in Bielefeld. Based on the experiences people had, a variety of emotions and emotional utterances were connected with these insecurities. Motorists felt anger about the perceived restrictions of mobility which were often regarded as artificial and unnecessary constraints to their civil freedoms². Pedestrians and Cyclists experienced fear caused by latent or manifest dangers, often caused by other traffic participants ${ }^{3}$. After deadly accidents, massive protests and the occupation of streets and public places were common. Social phenomena like road rage or the hedonistic-ruthless speeders were criticized in public as well as the statistically apparent peak of road safety issues, like the heavily rising numbers of dead and injured in the second half of the 1980s. The newspapers in town reported frequently about speeders, rude cyclists and aggressive driving, or interviewed people who spoke about their fear to participate in "the battlefield we call traffic»*. Roadside memorials gave

2 The connection between traffic restrictions and civil freedom seems to be a specific German mentality. A plausible theory would be that mass motorization and the first democratic state which guaranteed and supported a civil society were supported at the same time after 1949. Being mobile with a car and being a free citizen were two aspects of a concept of a society.

3 Bielefeld suffered a destruction of more than $90 \%$ of all buildings in World War 2. After 1945, the reconstruction process included decisions to make the new city more compatible with the expected development towards mass motorization. The public space became redistributed in favor of the car. It was considered as modern to have a city supporting the use of cars as the primary means of transportation. As a result, walkways were made smaller, roads got more lanes. About the history of mobility in Bielefeld see: Deppe 1992; Kühne 2006, 6ff; Haefeli 1999, 238-259; Vogelsang 1990, 74-85.

4 Statements like this were not unique in the analyzed sources, like newspaper articles, interviews and material of grassroots-level-social movements. Traffic being described with martial or bellicious metaphors was a common thing since the 1950s. See as well StBie 210,47 Bielefelder Stadtblatt/002: Verkehrsberuhigung, Tempo 30 
witness of the grief families felt for the death caused by traffic accidents [Röhl 2008, 5916-5927]. Local elections and campaigns in Bielefeld considered the issue of road safety, and political factions felt obliged to deliver answers and solutions. People had a feeling that traffic in their town was not safe, despite official statistics telling the opposite. In the elections for the city council in 1994, the green party managed to mobilize people by presenting a political agenda which included road safety promised changes concerning notorious accident hotspots. Their political success was founded on their program addressing people's emotions concerning the immanent insecurities.

My history of the emotional aspects of road safety in Bielefeld is focusing on the expectation, perception and social negotiation of risk ${ }^{5}$. The presumption is that politics and emotions share a fundamental connection ${ }^{6}$. Emotions are being understood as a natural part of political language and action'. They cause political actions, and are as well part of political acting. Every society has certain "feeling rules», which can change and develop over time [Reddy 2001, 124ff; Saxer 2007, 7]. My master thesis [Höltje 2014] presented the relevance of accidents as critical events for local communications of road safety and public security by analyzing three local case studies. In this article, I will show that both communication of insecurity and the production of security were connected to the management of emotions. To do so, exemplary communications will be analyzed concerning their semantic capabilities. In

Zonen 1984-1995, taz, 21.6.1989.

5 In this context ,risk ${ }^{*}$ is defined as a communication, a socially constructed entity, as outlined by Luhmann 2003. This sociological definition of risk stands in contrast to economic definitions, which are based on the assumption that every risks has a certain value and can be insured. About risks and emotions in traffic: Rölle 2010, 89-111; Jeschke 1994, 139-146.

6 This presumption is fundamental for many cultural approaches to security: Münkler 2010, 11-34.

7 About the history of emotions, defining and operationalizing emotions as historical categories: Frevert 2011; Reddy 2001; Hitzer 2011, 1-80; Aschmann 2005, 11. 
which context where emotions uttered by whom and to which end? Which emotions were in certain events expected or socially accepted? How was emotionality perceived by others? First I will present relevant terms and concepts such as the concept of securitization. Another brick are actors, institutions and the broader spatial and historical context of the local events. A third step deals with the communication of insecurity as a central manifestation of semantics with a capability for emotions. After that I will show that besides the imprecise use of language, insecurities were visualized in pseudo-precise statistics, which contributed to the overall social perception of security. Finally, I will show that the management of public security included managing the public emotions concerning insecurities.

\section{Communicating Emotions: Concepts and Terms}

'Traffic security' and 'road safety' are both referring to the German term 'Verkehrssicherheit' and representing a semantic disambiguation of it: 'road safety' meaning the technical aspects, 'traffic security' the broader, social dimension [Daase 2010, 2]. I will try to reflect this difference by referring to the more appropriate term in each context. My argument is that by the process of securitization, aspects formerly regarded as mere technical 'safeties' become embedded in the public and political center of attention and can therefore be described as 'securities'. As security is a central leitmotif of modern societies, the emotions caused by insecurities are a dominant factor in the communication of political concepts and agendas ${ }^{9}$. Security is not understood as a mere object of

8 "Securitization" means a process of communication which establishes topics as matters of security: Buzan et. al 1998. There, securitization was defined as a "social process by which groups of people construct something as a threat»: Buzan et. al 2009, 213, 214.

9 The German term 'Sicherheit' plays a crucial role in the history of Germany in 
government actions, but as a horizon of social and cultural beliefs and expectations [Conze 2005, 357-380]. The dilemma of security in modern societies is that citizens always demand more than the status quo. Like the gross national product or the individual income, security is always expected to increase.

Surely, the experience of insecurity is a very subjective and individual matter. But strong emotions like the feeling to risk one's life on a daily basis structure both social actions and communications of individuals. Even more, psychological research found incidence that feeling insecure might have meant mental problems for those who experienced it permanently [Maslow 1977, 45ff.]. The psychologist Abraham Maslow defined security as a basic necessity for human beings nearly as important as sleep or food. When permanently not feeling secure, a person will prioritize the reestablishment of security to all other needs, except the even more existential ones. Such a person might act in a restricted or self-focused way due to this phenomenon. The choice of the means of transportation, the time and place, as well as the possibility to be actively driving or being transported as a passenger all are factors for the overall perception and the individual opinion. In addition to that, the primary choice of means of transportation forms an individual set of values [Becker 1999, 86ff.] They are oriented on the self or the community and include economic, ecological, social and hedonistic values. If an individual experiences his core value to be disrupted, an emotional reaction is likely to follow. Aggressive driving was often a reaction to perceived restrictions by others. In Bielefeld, traffic congestions caused by high traffic density and construction zones increased the potential for these problems [Yorck Herzberg 2006, 79; Gerike 2011, 213]. But what insights can written sources offer about emotions? They deliver a perspective on the public use of emotions as a part of public 
speaking and acting [Saxer 2007, 15] On a more abstract level, they enable us to see the feeling rules of a society, the way emotions were socially constructed by language and coded into various texts, contexts, and representations. This is achieved by the use of a variety of linguistic expressions with different meanings, tonalities and connotations. These semantics of emotions can be identified with the following criteria: they must be i. immediately understandable by relevant others, ii. Accompanied by distinguishable physical changes, iii. Able of being demonstrated by verbal expressions, iv. Decodable by a cultural code [Frevert 2000, 98]. Emotions can be understood as the result of a translation process, forming individual feelings into articulations which are collectively understood. These "emotives» can be described as language-based representations which enable us to construct our perception of reality [Reddy 2001, 104f.]. From this perspective, the question if there is any emotion 'as such' is obsolete. If any emotion can only be expressed or even thought by the use of language, the semantic aspect of it is given by the semiotic fact that it is only a reference to something ${ }^{10}$.

\section{The Historical Context of Traffic Insecurities}

The debate about traffic safety is as old as motorized traffic itself. Yet there are just a very few historizations of the insecurities experienced in traffic, besides the historiographies of exceptional events like catastrophes as for example Titanic and Hindenburg. Fear and anger, as being common emotions of those participating in traffic, seem to be continuous but unappreciated aspects of the history of mobility. When technical systems are commonly used and considered as safe, the reality of eventual insecurity is even more striking. Only when a certain cata-

10 Referring to the semiotic Ogden/Richards triangle, meaning is only an indirect representation of concepts for real entities, named by language. 
strophe threshold is broken, events are being perceived as extraordinary and not acceptable ${ }^{11}$. Some accidents were perceived as beyond this threshold and functioned as "critical events», catalyzing the process of securitization $^{12}$. The dynamic momentum of such an event was able to change the perception of security in a way, that previously unspeakable or unthinkable options became more realistic. The threshold itself is the result of communication about risks and dangers and its social perceptions. Its exact position is relative to places, like the individual perspective on traffic, as well as to time.

If a situation occurs when the insecurity is considered as manifest and immanent, securitizing actors start a process of securitization leading to far-reaching institutional change. In the early 1970s, the amount of 20000 yearly deaths caused by traffic accidents evoked reactions by securitizing actors such as mass media [Gehlert 2011, 233]. In the years of the oil price crisis, the economical doubts concerning the future of traffic and motorization became connected with general critique of its insecurity by various social movements [Luhmann 1998, 852, 853]. Later in the 1980s, the same debate took place within the background of the Waldsterben-debate, even though the number of overall deaths had decreased massively. Road safety had become part of a broader debate about the social acceptance of risks and dangers. As a result, the formerly technical aspects of road safety were now discussed as a problem of public security. This process of securitization led to political

11 I am referring to the concept of «Katastrophenschwelle» as defined by Luhmann 2003, 11: "Catastrophes guide into another mode of political action, ignoring the usual processes and bureaucratic structures. If it comes to that, it is not about managing the security problem itself, it is about maintaining the political sovereignty in principle».

12 Gilcher-Holtey 2001, 120-137. Critical Events are events perceived and communicated as non-daily and exceptional. The point of time when the event takes place plays a crucial role in this concept. Decisions of participating actors can only be made in a short period of time after critical events, when the positions of many actors become synchronized and they all have to meet the demands for more safety. See as well: Gilcher-Holtey 2008, 15-47. 
concepts dealing with the new-found problem, and offering solutions to those who demanded them. The government, be it the local mayor and city council or the federal state, was expected to protect the citizens of this new-found threat [Habermas 2009, 406].

In the "era of ecology», mobility and traffic became topics of political relevance for the new social movements, which were in Germany linked with the New Left ${ }^{13}$. The first groups concerned with the insecurities of traffic were established in the post-1968 left-alternative milieu in the late 1970s, consolidated in the 1980s and became relevant actors in the political infrastructure in the early 1990s. As a part of the Verkehrsbewegung, small groups developed as Bürgerinitiativen. With expertise and dedication, they made a contribution to local political agendas and influenced decisions about the organization of traffic in the public space. Being a part of the alternative milieu, their message was that the established political factions were lacking real-world traffic concepts to solve existing problems. By the use of public speech, mass media and personal relationship to existing parties, they managed to make their points clear and gain local political influence within a few years. In the late 1980s the local milieu of new social movements involved in traffic security in Bielefeld had a heterogeneous structure. Small groups mainly consisting of neighbors were mainly interested in 'their' street, but partly became integrated in bigger structures. Clubs and interest groups began to reformulating their aims and addressing more people. In 1982, the local section of the cyclists-club (ADFC) was founded to represent the position of cyclists. In their initial leaflet, they justified their existence with the fact that «having no lobby can

13 Joachim Radkau chooses this term for the time after 1968: Radkau 2011, 147. About the history of new social movements in Germany: Neidhardt, Rucht 2001, 2870; Balistier 1983, 12; Kern 2008, 156, 157; Rootes 2004, 608-640; Neidhardt 1994, 7-41; Friedrichs 1994, 359-374. New Left and left-alternative Milieus, lifestyle and habitus was thoroughly researched by Reichardt 2014. 
be life-threatening $\gg^{\prime 4}$. Parallel to the grass-root-level of peace activists, environmentalists and anti-nuclear-power groups formed a Bunte Liste, which later merged to Bündnis 90 / Die Grünen. Those groups did not hesitate to name insecurities explicitly, talking of «an atmosphere of daily terror» and «criminal speeding»"s. By doing so they transformed private emotions into public emotions. Political mobilization was made by addressing these emotions directly.

\section{Playing the Game of Chance: Emotional Perceptions of Traffic}

The rare mentioning of emotions in the sources may as well be caused by habitual restrictions. In many social milieus, fear was simply not part of the constructed identity of the unfettered citizen. In addition to that, it was simply not common to speak about emotions in public. Emotions were connected to the private life, and could not easily be communicated in public without leaving the narrow sphere of social acceptability. The sources contain only little evidence of people speaking directly of fear. Metaphors and indirect references were more common. For instance, the traffic was often described as a catastrophe or catastrophic. Women had "fear as a constant companion» when participating in traffic ${ }^{16}$. Cyclists experienced the new-designed Adenauerplatz in Bielefeld as a place where «fear for their life» or «a condition of fear» were typical reactions to the use of the cycle lane. In 1979, the student Marita Apfelbacher wrote a letter to the chief of police in which she stated that after two accidents as a cyclist, she would

14 StBie 210,47 Bielefelder Stadtblatt/032: Radfahren I 1973-1989, «Stadtblatt», $1 / 1983$.

15 StBie 210,47 Bielefelder Stadtblatt/002: Verkehrsberuhigung, Tempo-30-Zonen 1984-1995, NW 18.7.1991.

16 StBie 210,47 Bielefelder Stadtblatt/032: Radfahren I 1973-1989, NW 6.3.1980. 
refuse to participate in this "game of chance» by riding her bike on the road $^{17}$. Instead, she would be using the sidewalk, to increase her safety to an acceptable level and not putting her life at the stakes. The police responded by informing her that illegal usage of sidewalks could be charged. It was also the chief of police who advised cyclists to consider not using their bicycles any more due to the dangers connected with it. The message was understood; the police admitted that they could not provide safety for all to the same degree ${ }^{18}$.

Since the early 1980s the number of cyclists in Bielefeld increased and to a formerly unknown level in the middle of the 1990s. This development caused conflicts about security between different users of the public space. Cyclists tended to use pedestrian areas where no cycle lanes were available to avoid the feared contact with cars. When many cyclists began to use the pedestrian mall in the city center to avoid the notorious main roads, pedestrians considered this practice as an invasive and rude threat to their safety. Local managers of public security were demanded with an incredible medial resonance to act against "cycling rowdies»'. The police reacted with intensive controls in the affected areas, earning positive resonance by the media by fining the caught cyclists. In their opinion, the cyclists caused the massive increase of accidents by their general «lack of discipline» and by not complying with traffic rules, like their "occupation» of sidewalks and ignoring red lights ${ }^{20}$. With a high visibility, the police tried to reestablish the "comfort and freedom from danger» for pedestrians. The police officer in charge explained the strategy which was explicitly targeting

17 StBie 210,47 Bielefelder Stadtblatt/032: Radfahren I 1973-1989, NW 6.10.1979.

18 StBie 210,47 Bielefelder Stadtblatt/032: Radfahren I 1973-1989, NW 3.2.1979.

19 StBie 210,47 Bielefelder Stadtblatt/030: Radfahren II 1993-1995, WB 7.8.1995.

20 StBie 210,47 Bielefelder Stadtblatt/032: Radfahren I 1973-1989, NW 9.6.1983; StBie 210,47 Bielefelder Stadtblatt/032: Radfahren I 1973-1989, NW 23.6.1989. 
the emotions: "Comfort and security means quality for life»"1.

The protests taking place in Bielefeld almost habitually after each critical event can also be interpreted as valves for this psychological problem. These emotions were not only on the level of social constructions, but existed biologically, and motivated people to join the protests. It was not necessary to be a victim by own experience to develop negative emotions about traffic security. Persons living in the city experienced traffic accidents as part of daily life. Victims of traffic accidents were known to nearly everyone. The perception was also influenced by the media reporting about local accidents regularly and by social contacts reporting about self-experienced or watched accidents [Reichertz 2010, 40-60]. People joined the protests because they were feeling concerned and had fear for their health or life. The mass media played a crucial role in reflecting the role of the protests. Via their reflection in the public opinion, the social movements and each participant were able to watch themselves and form a social identity [Kern 2008, 156, 157] People speaking about having fear when partaking in traffic often where in marginalized positions, until their issues became a part of social movements' political agendas.

Emotions also have influence on the behavior in the public sphere, the use of traffic infrastructure and practices of use [Rölle 2010, 89-111; Jeschke 1994, 139-146] Different individuals have different emotional settings depending on their dominant form of mobility. A survey made in Bielefeld in 1994 by a city-run project group gives an overview about the emotional setting a citizen might have had about participating in traffic.

Conspicuously many cyclists declared to experience fear as the strongest emotion while cycling, prior to anger or happiness ${ }^{22} .45,8 \%$ stated

21 StBie 210,47 Bielefelder Stadtblatt/031: Radfahren II 1991-1993 , Stadtblatt 40/1990.

22 StBie 210,47 Bielefelder Stadtblatt/030: Radfahren II 1993-1995, Stadtblatt 
that they would not use the bicycle at all due to fear. $45 \%$ of all persons being mobile exclusively by foot and $40 \%$ of all exclusively motorists stated that the choice of means of transportation was mainly based on their personal feelings. For those, the bicycle was considered as unacceptably insecure. $68,2 \%$ of all surveyed persons stated the car traffic to be the biggest overall threat, $77,4 \%$ of all cyclists agreed to this statement. Besides fear, forms of anger up to manifest aggression were considered as common emotions for more than $50 \%$, no matter what the means of transportation were. $60 \%$ thought of cyclists as having a positive effect on overall road safety. Of all surveyed persons, $78 \%$ said that they would be willing to use the bike more often, if they would feel safer. A completely car-free city was expected to increase overall safety by $58 \%, 17 \%$ denied an increase at all.

Fear as an emotion was often being addressed in political arguments. Especially the debate about $30-\mathrm{km} / \mathrm{h}$-zones was shaped by illustrating the physical results of accidents with higher speed. The local initiative Gruppe aktiver Radfahrerinnen und Radfahrer (GAFF) designed leaflets with a morbid sepulchral aesthetic. A coffin for the 8000 dead by traffic accidents, decorated with stars like the Mercedes-Benz-logo and a black ribbon designed like a street. Additionally, the reference to children as possible victims of accidents was a common argument to convince adults to change their behavior. It was always an appeal towards morality, but also raised fears that one's own child might be a victim as well. Alas, the fear of becoming a victim of an accident caused by excessive speeding did not stop the majority of motorists to surpass the speed limit by smaller amounts. Traffic controls granted high tolerances at the measure threshold, subtracting at least 10\%. Complaints about cars driving with $70-80 \mathrm{~km} / \mathrm{h}$ or $40-50 \mathrm{~km} / \mathrm{h}$ were common. Many local initiatives documented with borrowed radar equipment 
the speed excesses in 'their' street ${ }^{23}$. The newspapers reported of "angry accusation» and "situations prone to a brawl» when the speeders were confronted by the residents. People who were speeding in the city were commonly addressed as insane, anti-social or as mere criminals. If they belonged to certain subcultures like car-tuners, their social position often became marginalized and reduced to the opinion that they would be a threat to others ${ }^{24}$. The public demands for exclusive punitive action became a routine of social distinction against 'the others' with the side-effect of reducing the complexity of the problem. Speeding was considered to be the most important reason for severe accidents, and the few persons who committed to speeding were found guilty in public opinion. By performing this mechanism of othering, the public guilt and blame was addressed to the others, whereas the own behavior was being constructed as socially acceptable. By inventing the speeder as not normal, the own speed became normal.

\section{Communicating Risks by Numbers}

Concerning the numbers of accidents Bielefeld was following the general trend in the Federal Republic. The degree of motorization was, in comparison to other cities of the same size, average. Since the early 1950s, the city administration ran an image-campaign to establish Bielefeld as a 'car-friendly city', following the paradigmatic urban development doctrine in those days [Haefeli: Verkehrspolitik, 241, 242]. The consequence was that after 1965, the proportion of motorized traffic to other forms of mobility became massive, leading to further

23 StBie 210,47 Bielefelder Stadtblatt/001: Raser, Tempolimit, Geschwindigkeitsüberwachung 1989-1996, NW 7.7.1994.

24 StBie 210,47 Bielefelder Stadtblatt/001: Raser, Tempolimit, Geschwindigkeitsüberwachung 1989-1996, Stadtblatt 2.1.1994. 
problems such as increasing accident rates for all traffic participants. In 1973, the number of death caused by traffic was at an absolute peak ${ }^{25}$. Regarding the long-term trend of accidents, deaths and injuries, it is clear that the total number of accidents increases until today. Despite, the total deaths decrease since the peak in the early 1970s, increasing only slightly after the German unification in the early 1990 s.

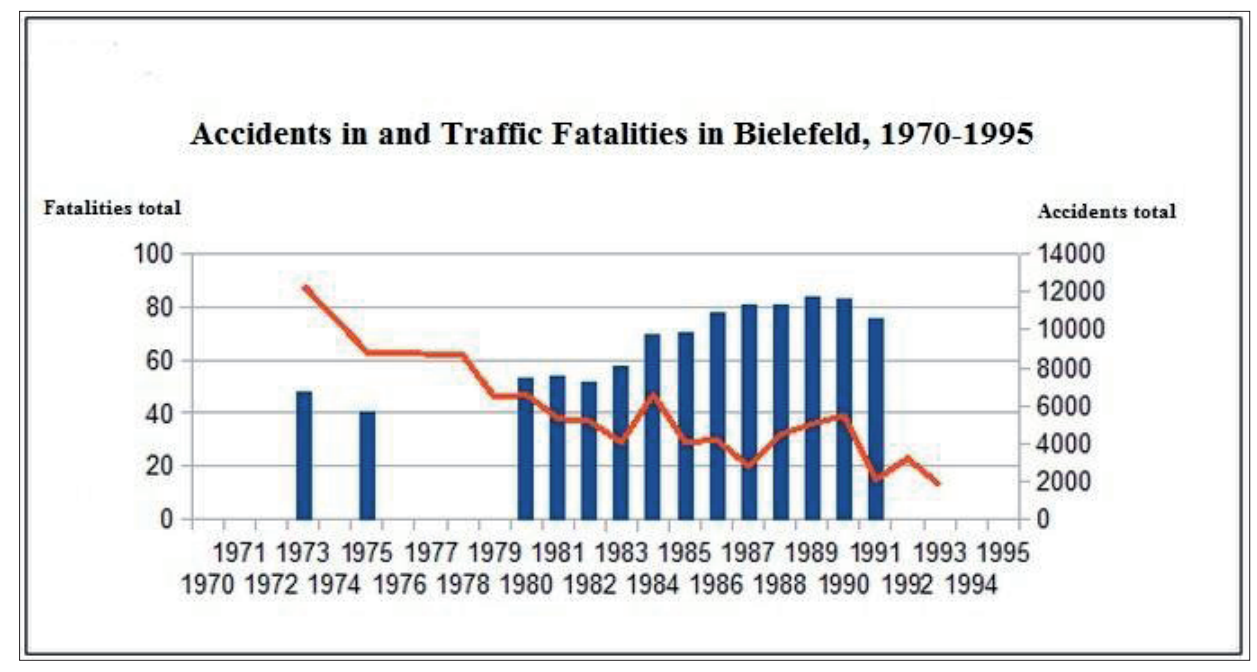

This was the official graph shown by those who were in charge to guarantee public security, like the police and politicians. This convention of visualization helped forming a narrative of always increasing security, being reproduced at annual press conferences and publications. Showing declining graphs not only proved the efficiency of the own work, it also calmed down the emotions in the public opinion concerning security. After a series of deadly accidents in 1983, the chief of police demanded the "weak traffic participants», he meant cyclists and

25 In 1970, the sum of dead and heavy injured persons in Germany was 550.988 and in 1995 521.595. The total amount of accidents in 1970 was 1.392.007, in 1995 2.238.301: https://www.destatis.de/DE/ZahlenFakten/Wirtschaftsbereiche/TransportVerkehr/Verkehrsunfaelle/Tabellen_/Strassenverkehrsunfaelle.html 
pedestrians, not to rely on the consideration of motorists ${ }^{26}$. Instead, they should behave more cautious to avoid future accidents. This statement enraged the concerned groups even more, they felt treated like secondclass citizens and got the impression that their feeling of insecurity was well-founded.

In Bielefeld, the numbers followed the general trend ${ }^{27}$. However, in the 1980s the number of deaths decreased significantly less than the German average. In 1987 to 1991 there was an increase of casualties no one really could explain. Taking a closer look at the modal split, dividing the total number in separate trends for motorists, cyclists and pedestrians, reveals a different development. The numbers for motorists followed the general trend and declined, whereas the number for other participants in traffic increased. For those the probability to suffer a deadly or severe accident were significantly higher, and statistical reasons for emotions like fear and the overall feeling of insecurity definitely existed. Motorists profited from safety innovations like airbags and seat belts and even drove more risky than they had ten years ago, but

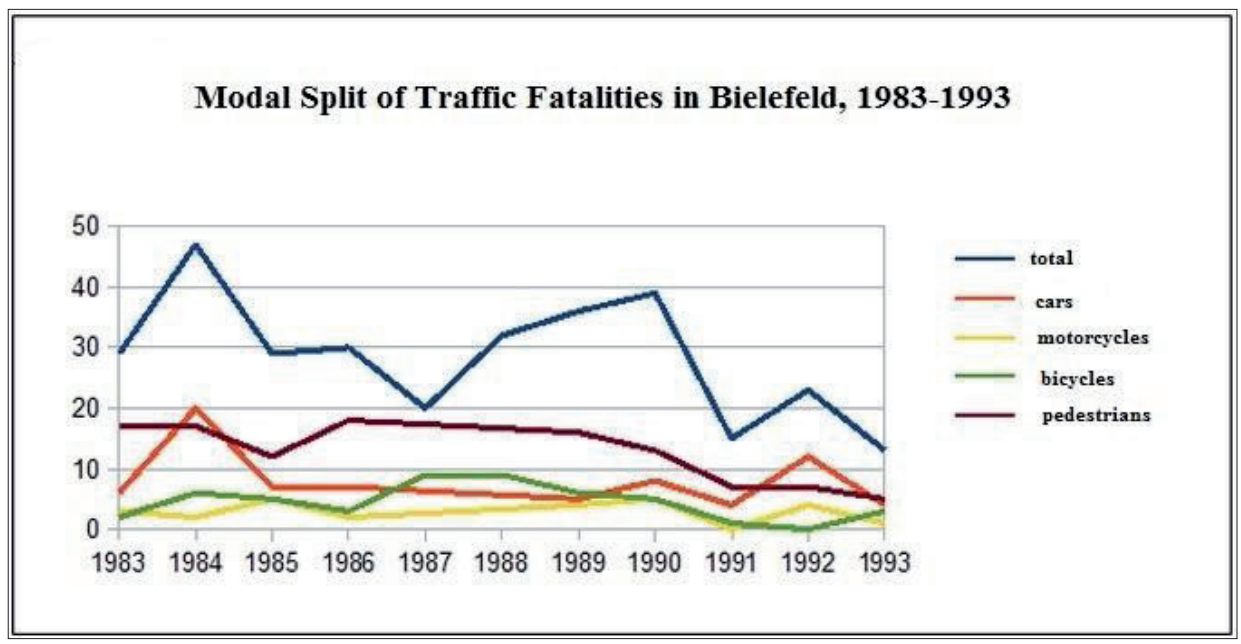

26 StBie 210,47 Bielefelder Stadtblatt/004: Verkehrsunfälle, Verkehrssicherheit 1986-1989, NW 27.4.1983.

27 The numbers have recorded in the official yearbooks of the city, published by the department for statistics, and available in the city archives. 
without the deadly effects.

All others suffered the increasing rate of motorization. AutoBild, one of the mainstream automotive magazines without any tendency against motorized traffic in general, in 1987 had the headline «Bielefeld is Germany's' least secure town», hinting at the unexpected peaks in the figures $^{28}$. In a comparison with 19 other German towns, Bielefeld got worst results concerning traffic safety. Of course this news had an impact on the local discussion, and were cited by critics of the established traffic concepts. The administration and the police denied the value of the survey, but the damage was done. Instead of reproducing the narration of permanently increasing security, the report showed a different picture than the official statistics. The efforts of the local security managers had been focused on decreasing the number of deadly accidents and showing this success with visualizations, dismissing other factors like severely injured or total accidents in relation to total inhabitants. The aim was to maintain a positive public opinion concerning security. In the years after the report traffic security was described as "a myth", and the local mass media reported frequently about accidents, keeping a close eye on the reactions and the explanations of police and city officials $^{29}$.

\section{Political Repercussions of Insecurity}

The demands for more security were common and the most exposed security managers in the city, the local police and the administration, tried to meet them by facing the problems. In 1991, after a cyclist had

28 This report was cited in the local press as well: StBie 210,47 Bielefelder Stadtblatt/004: Verkehrsunfälle, Verkehrssicherheit 1986-1989, Stadtblatt 15.4.1987.

29 StBie 210,47 Bielefelder Stadtblatt/008: Autowahn und Technik, Auto- und Verkehrsclubs 1984-1992, Die Zeit 8.11.1991. 
been killed in an accident caused by excessive speeding in the city center, some statements in the press were expressing it with emotional terms:

«Speeders are everywhere, the police isn't able to stop them. If the state fails to guarantee security, and if the politics does not react, the citizens must help themselves. In this case, installing concrete blocks and other obstacles become nothing else but a defensive action. It would not be necessary, if the state would free us from those brainless speeders. $\rangle^{30}$

Juvenile speeders connected risky driving at high speed with positive emotions, acted to impress one another and gain social capital in their peer group [Gehlert 2011, 238] The low compliance of traffic participants with existing rules was a major reason for traffic accidents. Speeding, crossing red lights and tailgating increased the rate of heavy accidents in the 1980s and 1990s massively ${ }^{31}$. Motorists, cyclists and pedestrians were both victims and delinquents. The efficiency of formal traffic policing was commonly doubted. The subjective probability of getting caught was low and motivated many persons to ignore the rules whenever a higher personal benefit was expected in comparison to the perceived possibility of negative outcomes and sanctions ${ }^{32}$. This was caused by the objective control density of the police, and the perceived level of surveillance. The personal perception was influenced by

30 StBie 210,47 Bielefelder Stadtblatt/002: Verkehrsberuhigung, Tempo-30-Zonen 1984-1995, NW 18.7.1991.

31 StBie 210,47 Bielefelder Stadtblatt/004: Verkehrsunfälle, Verkehrssicherheit 1986-1989, WB 8.3.1984.

32 Gehlert 2011, 243. In the middle of the 1990s, the police tried to confront people who committed traffic violations like speeding with possible consequences of their acting by showing them videos. The idea was to try a new method to accomplish a behavioral change not by fining and further punishment, but by shocking them. The video were thought to address the emotional set of the delinquent person and evoking fear of possible consequences. Soon after the introduction of this method, traffic psychologists doubt the effectiveness of the method. Studies reported about many participants reacting bored, ignorant or even mocking when being 'shocked' by the videos. 
many factors, structured the behavior. The police was restricted in its resources to control the traffic as well as in their will to do so.

After the early 1970s, the German police tried to change their public image. As a «friend and helping hand» of the citizens, it was counterproductive to bother the mobile citizens with too many restrictions. On the other hand, it was expected of the police to maintain the public security by sanctioning those who did not stick to rules. In the local media in Bielefeld, the reports about traffic controls had different tonalities depending on the time and the context. Shortly after accidents which functioned as critical events more security and more surveillance were demanded, but in general the media reproduced the message of surveillance as restrictions of the righteous citizen. The citizens as well reacted ambivalently when being controlled. In letters to the editor, people wrote about the "hate» and the «blind rage» they would feel when being controlled by machines and fined for speeding ${ }^{33}$. Other persons reacted quite emotional with the use of violence against installed cameras. To improve the public acceptance of controls and the general image of the police, surveillance activities were announced with martial rhetoric, like having a "mission to protect» children and elderly people, "declaring war on speeding in the city», "opening the hunt» on speeders or "starting an offensive» against them ${ }^{34}$. The necessity of the measures was always emphasized, and stated that it would be the natural task of the police to control the traffic and sanction deviant behavior. Even excuses about the "obligation to perform this unpopular task» were uttered by officials ${ }^{35}$. Traffic controls were announced days

33 Bielefelder Stadtarchiv, 210,47 / Bielefelder Stadtblatt 001, Westfälische Nachrichten $7 / 94$.

34 StBie 210,47 Bielefelder Stadtblatt/004: Verkehrsunfälle, Verkehrssicherheit 1986-1989, WB 12.6.1986; StBie 210,47 Bielefelder Stadtblatt/004: Verkehrsunfälle, Verkehrssicherheit 1986-1989, NW 11.12.1987.

35 StBie 210,47 Bielefelder Stadtblatt/004: Verkehrsunfälle, Verkehrssicherheit 1986-1989, WB 12.6.1986 
ahead, and radio stations as well as newspapers informed legally about time and places of the controls. As a result, the effectiveness of the controls itself decreased. The police could do its job and enact itself as an active producer of security, but without harming too many people by fining them. The actual security got undermined by these practices to maintain a fragile discursive equilibrium, but due to the medial resonances and the visibility of the police in the streets, the perceived security increased. By doing so, the police managed not the underlying road safety issues, but the feelings of those who were controlled as well as of those who demanded more controls.

After a deadly accident happened in 13 January 1986 at the Stapenhorststraße, a local initiative distributed a leaflet which said that the next deadly accident was just a matter of time, and posed the question what would have to happen to make a difference. The accident was considered as "not surprising or uncommon, but very expectable» ${ }^{36}$. The reproach was, that the persons and institutions in charge would just wait, until another accident happens, and not being actively preventing this from happening. The threat itself was considered as inevitable if nothing changed. The latent feelings of insecurity got manifest and found an expression at the demonstrations which took place in the days after the accident. After the critical event, appeals to peoples' emotions activated many persons to express their opinion in public: «concerned and angry cyclists» reminded others that «they could be the next victims $»^{37}$. The local media reported about the events and also integrated the emotions of the participants in their articles. The communication after the accident at the Stapenhorststraße is a prime example for how public opinion and political action change after critical events. The feeling of insecurity transformed from latent, but vague fear to a

36 Archiv der Universität Bielefeld KS 50Flugblatt vom 15.1.1986: Wieviele noch?; StBie Landesgeschichtliche Bibliothek Zst 22: Radblatt 1984-1988, 4/86, 1/86.

37 Ibid. 
manifest security problem. Tied up to the already existing and voiced discontent with the provision of security in traffic by the local institutions, protests intensified and finally got the undivided support of the local newspapers. The city administration was broadly considered as incapable of protecting the citizens. Hence to increase the security immediately, activists installed traffic signs displaying an allowed speed of $30 \mathrm{~km} / \mathrm{h}$, which were removed regularly by the city administration. As the protests lasted for weeks, political actors among all factions reacted to the changed public opinion by first modifying their language and then their actions concerning traffic safety. Now they had to react to present themselves as being active managers of the situation. Even conservative politicians, who never supported traffic safety agendas before and had barely credibility among the activists, were not reluctant to call the situation «a catastrophe» ${ }^{38}$. As a result, the city council decided urgently about a large-scale reconstruction of the whole street, a massive change in infrastructure to increase the security.

\section{Conclusion}

Semantics with emotional capability legitimized action and increased the impact of arguments. Speaking of fear made the threat more credible, even if the reference was merely a subjective feeling. The discourse about public security, explicitly including road safety, changed massively from 1979 to 1995. Especially the social acknowledgement and acceptance of emotions was a subject of change. In the 1990s, it was common to speak about having fear when cycling, or being aggressive when being decelerated by others. The social movements, later in their more institutionalized forms as parties, played a huge role in this process. They were the driving forces who accepted existing emotions

38 StBie 210,47 Bielefelder Stadtblatt/011: Straßen 1977-1992, WB 16.1.1986. 
which were considered as unspeakable in public, and integrated them in their political rhetoric and agendas. This lead to political success and on the long run to social change. Further research on the history of emotions seems promising, especially when being performed with progressive methods in interdisciplinary contexts. A cultural history of mobility can add new perspectives of the self-perception of societies and the communication of risks. This might help to understand the history of the 20th century as well as the unsolved traffic problems of the presence.

\section{Sources}

Archiv der Universität Bielefeld KS 50

Stadtarchiv Bielefeld $=$ StBie

StBie 210,47 Bielefelder Stadtblatt/001: Raser, Tempolimit, Geschwindigkeitsüberwachung 1989-1996

StBie 210,47 Bielefelder Stadtblatt/002: Verkehrsberuhigung, Tempo 30 Zonen 1984-1995

StBie 210,47 Bielefelder Stadtblatt/004: Verkehrsunfälle, Verkehrssicherheit 19861989

StBie 210,47 Bielefelder Stadtblatt/008: Autowahn und Technik, Auto- und Verkehrsclubs 1984-1992

StBie 210,47 Bielefelder Stadtblatt/011: Straßen 1977-1992

StBie 210,47 Bielefelder Stadtblatt/030: Radfahren II 1993-1995

StBie 210,47 Bielefelder Stadtblatt/032: Radfahren I 1973-1989, Stadtblatt 1/1983

StBie Landesgeschichtliche Bibliothek Zst 22: Radblatt 1984 - 1988

https://www.destatis.de/DE/ZahlenFakten/Wirtschaftsbereiche/TransportVerkehr/ Verkehrsunfaelle/Tabellen_/Strassenverkehrsunfaelle.html (12.06.2012) 


\section{Reference List}

Aschmann B. 2005, Vom Nutzen und Nachteil der Emotionen in der Geschichte. Eine Einführung, in Aschmann B. (ed.), Gefühl und Kalkül. Der Einfluss von Emotionen auf die Politik des 19. Und 20. Jahrhunderts, München, 9-32.

Balistier T. 1996, Straßenprotest. Formen oppositioneller Politik in der Bundesrepublik Deutschland zwischen 1979 und 1989, Münster.

Becker R. 1999, Mobilität und Werte. Ein wertepluralistischer Ansatz zur Erklärung der Verkehrsmittelnutzung und der Zustimmung zu verkehrspolitischen Maßnahmen, Trier.

Bergmann H. 2009, Angeschnallt und los. Die Gurtdebatte der 1970er und 1980er Jahre, «Technikgeschichte», (76): 105-130.

Berkowitz L. 1989, Frustration-Aggression Hypothesis: Examination and Reformulation, «Psychological Bulletin», (106): 59-73.

Böhm S. 2006, Against Automobility, Malden MA.

Buzan B. et. al 1998, Security. A new framework for analysis, Boulder.

- et. al 2009, The evolution of international security studies, Cambridge MA.

Briggs B. 1977, The war against the automobile, New York.

- 2005, Sicherheit als Kultur. Überlegungen zu einer "modernen Politikgeschichte” der Bundesrepublik Deutschland, "Vierteljahreshefte für Zeitgeschichte», (53): 357-380.

Conze E. 2009, Die Suche nach Sicherheit. Eine Geschichte der Bundesrepublik Deutschland von 1949 bis in die Gegenwart, München.

Daase C. 2010, Der erweiterte Sicherheitsbegriff, Göttingen.

- 2012, Die Historisierung der Sicherheit, "Geschichte und Gesellschaft», (38): 387-433.

Dahlen E. R. et. al. 2005, Driving anger, sensation seeking, impulsiveness, and boredom proneness in the prediction of unsafe driving, "Accident Analysis \& Prevention", (37): 341-348.

Deaux K. K. 1971, Honking at the intersection, "The Journal of Social Psychology», (84): 159-160.

Deppe M. 1992, Verkehrsunfälle als gesellschaftliches Ereignis, mit besonderer Berücksichtigung des Bielefelder Raumes in den 1950er Jahren, Bielefeld.

Dienel H. L. 2007, Verkehrsgeschichte auf neuen Wegen, "Jahrbuch für Wirtschaftsgeschichte» (1): 19-39.

- 2010, Die moderne Straße. Planung Bau und Verkehr vom 18. bis zum 20. Jahrhundert, Frankfurt.

Gehlert T. 2011, Verkehrssicherheit, in Schwedes O. (ed.) 2011, Verkehrspolitik, Wiesbaden, 233-251.

Gerike R. 2011, Das Phänomen Stau, in Schwedes O. (ed.) 2011, Verkehrspolitik, Wie- 
sbaden, 213-231.

Gilcher-Holtey I. 2001, "Kritische Ereignisse” und "kritischer Moment”. Pierre Bourdieus Modell der Vermittlung von Ereignis und Struktur, in Suter A. (ed.) 2001, Struktur und Ereignis, Göttingen, 120-137.

- 2008, Mai 68 in Frankreich, in Gilcher-Holtey I. (ed.) 2008, 1968. Vom Ereignis zum Mythos, Frankfurt am Main, 15-47.

Fraunholz U. 2002, Motorphobia. Anti-automobiler Protest in Kaiserreich und Weimarer Republik, Göttingen.

Frevert U. 2000, Angst vor Gefühlen? Die Geschichtsmächtigkeit von Emotionen im 20. Jahrhundert, in Nolte P. et. al (ed.) 2000, Perspektiven der Gesellschaftsgeschichte, München, 58-78.

- 2009, Was haben Gefühle in der Geschichte zu suchen?, "Geschichte und Gesellschaft», (35): 183-208.

- 2011, Gefühlswissen. Eine lexikalische Spurensuche in der Moderne, Frankfurt am Main.

Friedrichs J. 1994, Stresemannstraße. Eine Fallstudie zur Dynamik sozialen Protests, in Neidhardt F. (ed.) 1994, Öffentlichkeit, öffentliche Meinung, soziale Bewegungen, Opladen, 359-374.

Habermas J. 2009, Faktizität und Geltung. Beiträge zur Diskurstheorie des Rechts und des demokratischen Rechtsstaats, Frankfurt am Main.

Haefeli U. 1999, Gas geben oder das Steuer herumreißen? Verkehrspolitik und Verkehrsplanung in Bielefeld nach dem Zweiten Weltkrieg, Historischer Verein für die Grafschaft Ravensberg (ed.), «Jahresbericht», (85): 238-259.

Hitzer B. 2011, Emotionsgeschichte - ein Anfang mit Folgen, 1-80, http://hsozkult.geschichte.hu-berlin.de/forum/2011-11-001.pdf

Höltje J. H. 2013, "Der Hinweis auf die Grenzen des politisch Machbaren im Verkehrssicherheitsbereich muss doch dort seine Glaubwürdigkeit verlieren, wo es ausschließlich um Rettung von Menschenleben geht”. Verkehrssicherheit in Bielefeld, 1979-1995, Bielefeld University.

Jeschke C. 1994, Persönliche Sicherheit - eine verhaltensrelevante Mobilitätsbedingung, in Flade A. et. al (ed.) 1994, Mobilitätsverhalten. Bedingungen und Veränderungsmöglichkeiten aus umweltpsychologischer Sicht, Weinheim, 139-146.

Kern T. 2008, Soziale Bewegungen. Ursachen Wirkungen Mechanismen, Wiesbaden.

Kühne H. J. 2006, Bielefeld '66 bis '77. Wildes Leben, Musik, Demos und Reformen, Bielefeld.

Luhmann N. 1998, Die Gesellschaft der Gesellschaft, Frankfurt am Main.

- 2003, Soziologie des Risikos, Berlin.

Lüthi B. 2009, Sicherheit und Mobilität. "Making the World a Safer Place?”, «traverse», $16(1): 15-25$. 
Maslow A. H. 1977, Motivation und Persönlichkeit, Olten.

Münkler H. 2010, Strategien der Sicherung: Welten der Sicherheit und Kulturen des Risikos. Theoretische Perspektiven, in Münkler H. (ed.) 2010, Sicherheit und Risiko. Über den Umgang mit Gefahr im 21. Jahrhundert, Bielefeld, 11-34.

Neidhardt F. 1994, Öffentlichkeit, Öffentliche Meinung, Soziale Bewegungen, in Neidhardt F. (ed.) 1994, Öffentlichkeit, öffentliche Meinung, soziale Bewegungen, Opladen, 7-41.

Neidhardt F., Rucht D. 2001, Protestgeschichte der Bundesrepublik Deutschland 19501994: Ereignisse, Themen, Akteure, in Rucht D. (ed.) 2001, Protest in der Bundesrepublik. Strukturen und Entwicklungen, Frankfurt am Main, 28-70.

Niemann H. 1999, Geschichte der Straßenverkehrssicherheit im Wechselspiel zwischen Fahrzeug, Fahrbahn und Mensch, Bielefeld.

Radkau, J. 2011, Die Ära der Ökologie. Eine Weltgeschichte, München.

Reddy W. M. 2001, The Navigation of Feeling, A Framework for the History of Emotions, Cambridge.

Reichardt S. 2014, Authentizität und Gemeinschaft, Berlin.

Reichertz J. 2010, Mediatisierung der Sicherheitspolitik oder: Die Medien als selbständige Akteure in der Debatte um (mehr) Sicherheit, in Groenemeyer A. (ed.) 2010, Wege der Sicherheitsgesellschaft, Wiesbaden, 40-60.

Rootes C. 2004, Environmental Movements, in Snow D. A. (ed.) 2004, The Blackwell companion to social movements, Malden MA, 608-640.

Rölle D. 2010, Unsicherheitsgefühle, Mediennutzung und Vertrauen in Institutionen. Empirisch belastbare Zusammenhänge oder Messartefakte?, in Groenemeyer A. (ed.) 2010, Wege der Sicherheitsgesellschaft, Wiesbaden, 89-111.

Röhl T. 2008, Symbole und die Bewältigung von Kontingenzerfahrungen. Private Erinnerungsmale für Unfalltote am Straßenrand, in Rehberg K. S. (ed.) 2008, Die Natur der Gesellschaft. Verhandlungen des 33. Kongresses der Deutschen Gesellschaft für Soziologie in Kassel 2006, Frankfurt am Main, 5916-5927.

Roth R. 2009, Allgemeine Überlegungen zum Verhältnis von Verkehr und Geschichte, in Roth R. (ed.) 2009, Neue Wege in ein neues Europa. Geschichte und Verkehr im 20. Jahrhundert, Frankfurt, 47-64.

Saxer D. 2007, Die Pragmatik der Emotionen im 19. und 20. Jahrhundert, "traverse. Zeitschrift für Geschichte», (2): 46-61.

- 2007, Mit Gefühl handeln. Ansätze der Emotionsgeschichte, «traverse. Zeitschrift für Geschichte», (2): 15-29.

Schiedt H. U. 2010, Verkehrsgeschichte, Zürich.

Siemens D. 2012, Das Narrativ der Krise in der deutschen Geschichte des 20. Jahrhunderts, in Zwierlein C. (ed.) 2012, Sicherheit und Krise. Interdisziplinäre Beiträge der Forschungstage 2009 und 2010 des Jungen Kollegs der Nordrhein-Westfälischen Akademie 
der Wissenschaften und der Künste 2012, Münster, 63-84.

Vogelsang R. 1990, Eine Verkehrskalamität. Der Ortsmittelpunkt Jahnplatz, in Hey B. (ed.) 1990, Geschichtsabläufe. Historische Spaziergänge durch Bielefeld, Bielefeld, 7485.

Yorck Herzberg P. 2006, Aggression und Aggressivität im Straßenverkehr, "Zeitschrift für Sozialpsychologie», 37 (2): 73-86.

Zwierlein C. 2012, Sicherheitsgeschichte. Ein neues Feld der Geschichtswissenschaften, "Geschichte und Gesellschaft» 38 (3): 365-386. 